\title{
A map of human impacts to a "pristine" coral reef ecosystem, the Papahānaumokuākea Marine National Monument
}

\author{
K. A. Selkoe · B. S. Halpern · C. M. Ebert • \\ E. C. Franklin · E. R. Selig · K. S. Casey • \\ J. Bruno $\cdot$ R. J. Toonen
}

Received: 16 December 2008/ Accepted: 26 February 2009/Published online: 25 March 2009

(C) The Author(s) 2009. This article is published with open access at Springerlink.com

\begin{abstract}
Effective and comprehensive regional-scale marine conservation requires fine-grained data on the spatial patterns of threats and their overlap. To address this need for the Papahānaumokuākea Marine National Monument (Monument) in Hawaii, USA, spatial data on 14 recent anthropogenic threats specific to this region were gathered or created, including alien species, bottom fishing, lobster trap fishing, ship-based pollution, ship strike risks, marine debris, research diving, research equipment installation, research wildlife sacrifice, and several anthropogenic climate change threats i.e., increase in ultraviolet (UV) radiation, seawater acidification, the number of warm ocean temperature anomalies relevant to disease outbreaks and coral bleaching, and sea level rise. These data were combined with habitat maps and expert judgment on the vulnerability of different habitat types in the Monument to estimate spatial patterns of current cumulative impact at
\end{abstract}

Communicated by Environment Editor Prof. Rob van Woesik

Electronic supplementary material The online version of this article (doi:10.1007/s00338-009-0490-z) contains supplementary material, which is available to authorized users.

K. A. Selkoe - E. C. Franklin · R. J. Toonen

Hawai'i Institute of Marine Biology,

University of Hawaii,

Kāne"ohe, HI 97644, USA

K. A. Selkoe $(\bowtie) \cdot$ B. S. Halpern · C. M. Ebert

National Center for Ecological Analysis

and Synthesis, 735 State St, Santa Barbara,

CA 93101, USA

e-mail: selkoe@nceas.ucsb.edu

E. R. Selig

Curriculum in Ecology, University of North Carolina at Chapel

Hill, Chapel Hill, NC 27599-3275, USA
1 ha $\left(0.01 \mathrm{~km}^{2}\right)$ resolution. Cumulative impact was greatest for shallow reef areas and peaked at Maro Reef, where 13 of the 14 threats overlapped in places. Ocean temperature variation associated with disease outbreaks was found to have the highest predicted impact overall, followed closely by other climate-related threats, none of which have easily tractable management solutions at the regional scale. High impact threats most tractable to regional management relate to ship traffic. Sensitivity analyses show that the results are robust to both data availability and quality. Managers can use these maps to (1) inform management and surveillance priorities based on the ranking of threats and their distributions, (2) guide permitting decisions based on cumulative impacts, and (3) choose areas to monitor for climate change effects. Furthermore, this regional analysis can serve as a case study for managers elsewhere interested in assessing and mapping region-specific cumulative human impacts.

Keywords Threat assessment - Vulnerability . Ecosystem-based management · Marine-protected areas · Northwestern Hawaiian Islands

Present Address:

E. R. Selig

Center for Applied Biodiversity Science, Conservation

International, 2011 Crystal Dr., Ste. 500, Arlington,

VA 22202, USA

\section{K. S. Casey}

National Oceanographic Data Center, National Oceanic and Atmospheric Administration (NOAA), 1315 East-West

Highway, Silver Spring, MD 20910, USA

J. Bruno

Department of Marine Sciences, University of North Carolina at Chapel Hill, Chapel Hill, NC 27599-3300, USA 


\section{Introduction}

Worldwide coral reef ecosystems have been transformed under the influence of direct and indirect effects of human activities (Bruno et al. 2007). Understanding the relationships between human activities and their ecological impacts and assessing the spatial distribution of these impacts are crucial steps in managing the use of coral reefs in a way that maximizes commercial and societal benefits while minimizing reef degradation. Recent policy emphasis on spatial management of the oceans (Crowder et al. 2006) suggests an urgent need for high-resolution maps of human activities and their ecological impacts. The Papahānaumokuākea Marine National Monument (Monument) surrounds the string of atolls and banks known as the Northwestern Hawaiian Islands (NWHI), a vast area stretching over $2,000 \mathrm{~km}$. A synthesis of the patterns of all types of human impacts across the archipelago can serve as a useful tool for managers implementing local scale spatial management of the Monument with an ecosystem-based perspective.

The isolated reefs of the Monument are considered to be relatively pristine compared with other coral reefs in closer proximity to human populations, such as the main Hawaiian Islands (Friedlander et al. 2005; Pandolfi et al. 2005). Field surveys have found that the reefs of the Monument have an unusual abundance of top predators, high fish biomass, low incidence of coral disease and large populations of sensitive seabirds, marine mammals and turtles that have been extirpated elsewhere (Harrison 1990; Friedlander and DeMartini 2002; Balazs and Chaloupka 2004; Parrish and Boland 2004; Kenyon et al. 2006). Nevertheless, the NWHI ecosystem has been affected by numerous past and on-going human activities (Friedlander et al. 2005, Heinemann et al. 2005). Information on the nature, extent, and locations of the ecological impacts of these activities is central to formulating management strategies and priorities.

Past approaches to evaluating the distribution and ecological impacts of human activities have almost all been tailor-made to a specific ecosystem type or management question and most used expert opinion to evaluate or rank the ecological impact of activities (reviewed in Selkoe et al. 2008). A well-known example is 'Reefs at Risk' (Bryant et al. 1998), which used an expert workshop to classify the world's coral reefs into low, medium, and high threat categories based on their distance to sites of four types of potential threats. While perhaps useful in some areas of the world, these results were less appropriate for the unpopulated and vast setting of the Monument, and some considered the approach lacking in scientific rigor (Sale 2008).

Recently, Halpern et al. $(2007,2008)$ introduced a new framework for evaluating and mapping the cumulative impact of human activities that is adaptable to a variety of scenarios and scales. This framework was applied at a global scale intended to comprehensively map the impacts of 17 human activities to all marine ecosystems (Halpern et al. 2008). However, the global scale of this analysis precluded the use of higher resolution data and information on threats unique to the Monument, such that the global results do not match basic expectations about the spatial patterns of impact within the Monument. Specifically, shallow areas appear less impacted than deeper areas despite human activities being concentrated on the more sensitive shallow reef areas in the NWHI (Fig. 1). Scientific experts on NWHI ecosystems identified a list of top threats to the NWHI that are quite different from the global analysis (NWHI: climate change, marine debris, and alien species; global: sedimentation, coastal development, and eutrophication) (Selkoe et al. 2008), providing a possible

Fig. 1 Map of the cumulative impact to the Hawaiian archipelago as assessed by the global-scale analysis (Halpern et al. 2008). Data are raw cumulative impact scores from a model that averages scores across overlapping ecosystem types (instead of summing as in the reported global results) for comparability to the methodology here

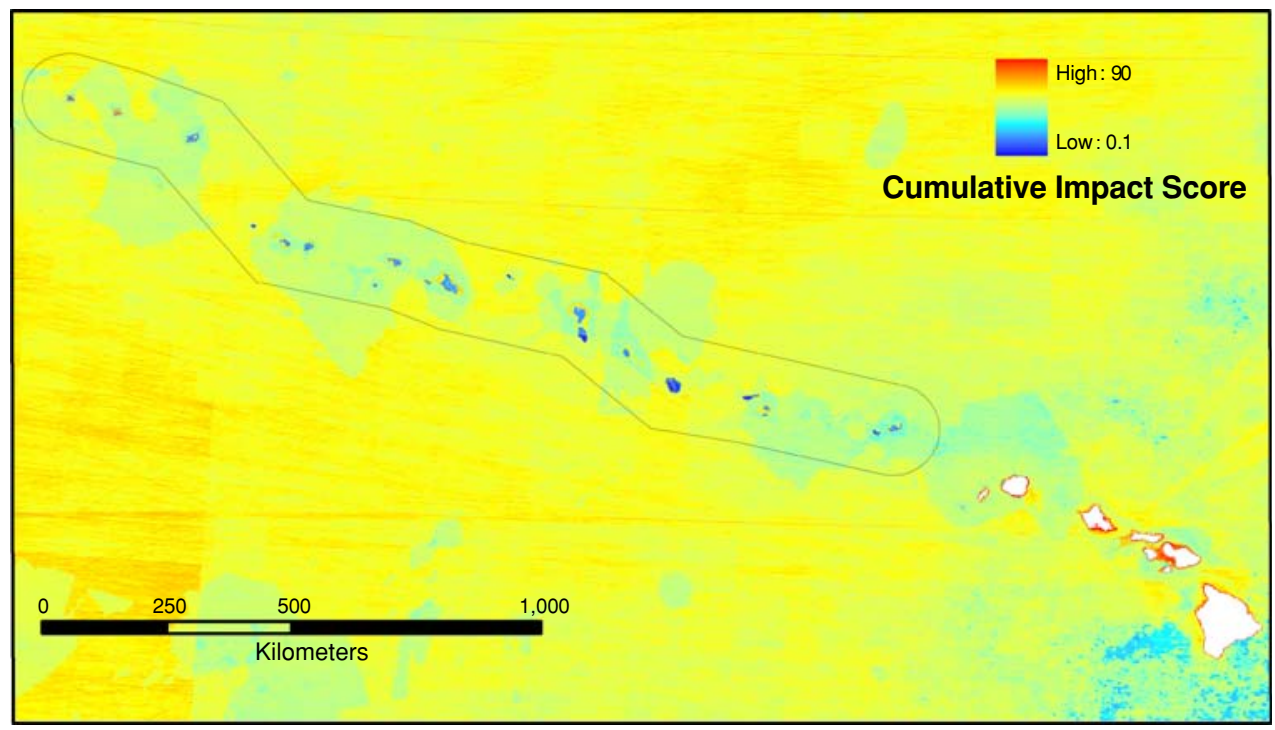


explanation for why the global map of human impacts poorly represents this unique area.

The cumulative impact mapping framework was applied here on a finer scale (1 ha resolution) with location-specific data to provide a more accurate and detailed view of the spatial distribution of cumulative impacts in the Monument. This analysis was intended to provide needed guidance to the Monument on where to apply different management regulations and which threats are most in need of attention, while also illustrating how the cumulative impact mapping framework (Halpern et al. 2007, 2008) can be applied to understand threats to any region at any scale. Comparing the new analysis to the global version also allowed us to directly assess the sensitivity of analyses conducted at different scales, and therefore better assess what is gained by conducting higher resolution analyses.

\section{Materials and methods}

\section{Framework for mapping human impacts}

The approach to mapping cumulative human impacts requires collection of three types of data that are combined to model relative total (cumulative) impact for every pixel on a map: (1) ecosystem or habitat presence/absence maps, (2) maps of the intensity of relevant human activities and associated stressors, and (3) vulnerability weights that describe how each ecosystem is expected to be affected by each stressor. The focus here was on data at $100 \mathrm{~m}$ resolution because of computational challenges working at finer grains and because management rarely requires or can act at finer resolution. These data allowed us to assess the ecological impacts of threats where they occur in a common currency for threats with different units (e.g., tons of fish caught vs. centimeters of sea level rise).

\section{Ecozone maps}

Ten distinct habitat types (called ecozones) within the Monument were designated so that vulnerabilities to anthropogenic threats could be compared among habitats (Table 1; Selkoe et al. 2008). Ecozones are physically distinct but sometimes interspersed benthic substrates that tend to have distinct community assemblages. However, many important taxa such as sea birds, turtles, monk seals, sharks, and jacks use many or all of the ecozones. Aside from biological and bathymetric differences, ecozones were distinguished by exposure and potential sensitivity to key human activities (e.g., inner and outer coral reef; see Selkoe et al. 2008). Areas below $200 \mathrm{~m}$ depth were not included because they are poorly described both physically and biologically, and are less of a focus by management plans.

Ecozones were mapped using existing digital habitat maps for the NWHI created by the National Oceanographic and Atmospheric Administration (NOAA). Details of the conversion of these habitat maps into the ecozone maps are included in the Electronic Supplementary Material 1. Data quality to classify benthic type varies by depth, such that ecozones are most accurate above $12 \mathrm{~m}$ depth. Between 12 and $30 \mathrm{~m}$, benthic type is often poorly defined, so "outer coral reef" is used as a default there such that algal beds, pavement, sand, and mud are underestimated in this zone. The final ecozone maps used in the study are shown for all atolls, reefs, and banks in Fig. 2.

\section{Human activities}

Any human activity with the potential to indirectly or directly drive the NWHI ecosystem away from its natural state was considered here. These activities interact with the ecosystem via associated drivers of change. These drivers are often referred to as "stressors" or "anthropogenic
Table 1 Ten ecozones used for the habitat-specific threat mapping in the NWHI

\begin{tabular}{|c|c|c|}
\hline ID & Ecozone & Description \\
\hline 1 & Inner coral reef & $\begin{array}{l}\text { Back reef and patch reef within atoll lagoons or partially sheltered from } \\
\text { swell and extensive flushing (e.g., areas of FFS) }\end{array}$ \\
\hline 2 & Outer coral reef & Coral-colonized fore reef to $30 \mathrm{~m}$ depth \\
\hline 3 & Deep reef or bank & Likely hard or sloped bottom $30-550 \mathrm{~m}$ depth \\
\hline 4 & Algal beds & Benthos dominated by dense macroalgae (e.g., Halimeda), $<30 \mathrm{~m}$ depth \\
\hline 5 & Rocky intertidal & Rocky coastline \\
\hline 6 & Sandy beach & Sandy coastline \\
\hline 7 & Interior terrestrial & Land, rock or sand not adjacent to water \\
\hline 8 & Pelagic habitat & Oceanic habitat outside deep reef boundaries \\
\hline 9 & Subtidal sand and mud & Soft bottom, mostly sand or mud habitats \\
\hline 10 & Subtidal pavement & Low relief uncolonized hard bottom and rubble \\
\hline 11 & Unknown/unclassified & Missing habitat data due to coverage or cloud gaps \\
\hline
\end{tabular}


Fig. 2 Ecozone maps for all atolls, reefs, and banks in the Papahānaumokuākea Marine National Monument are included in the study. Hawaiian names are given after English names. Rocky Intertidal Ecozone occurs at Gardner, Necker, and Nihoa in amounts too small to be visible here

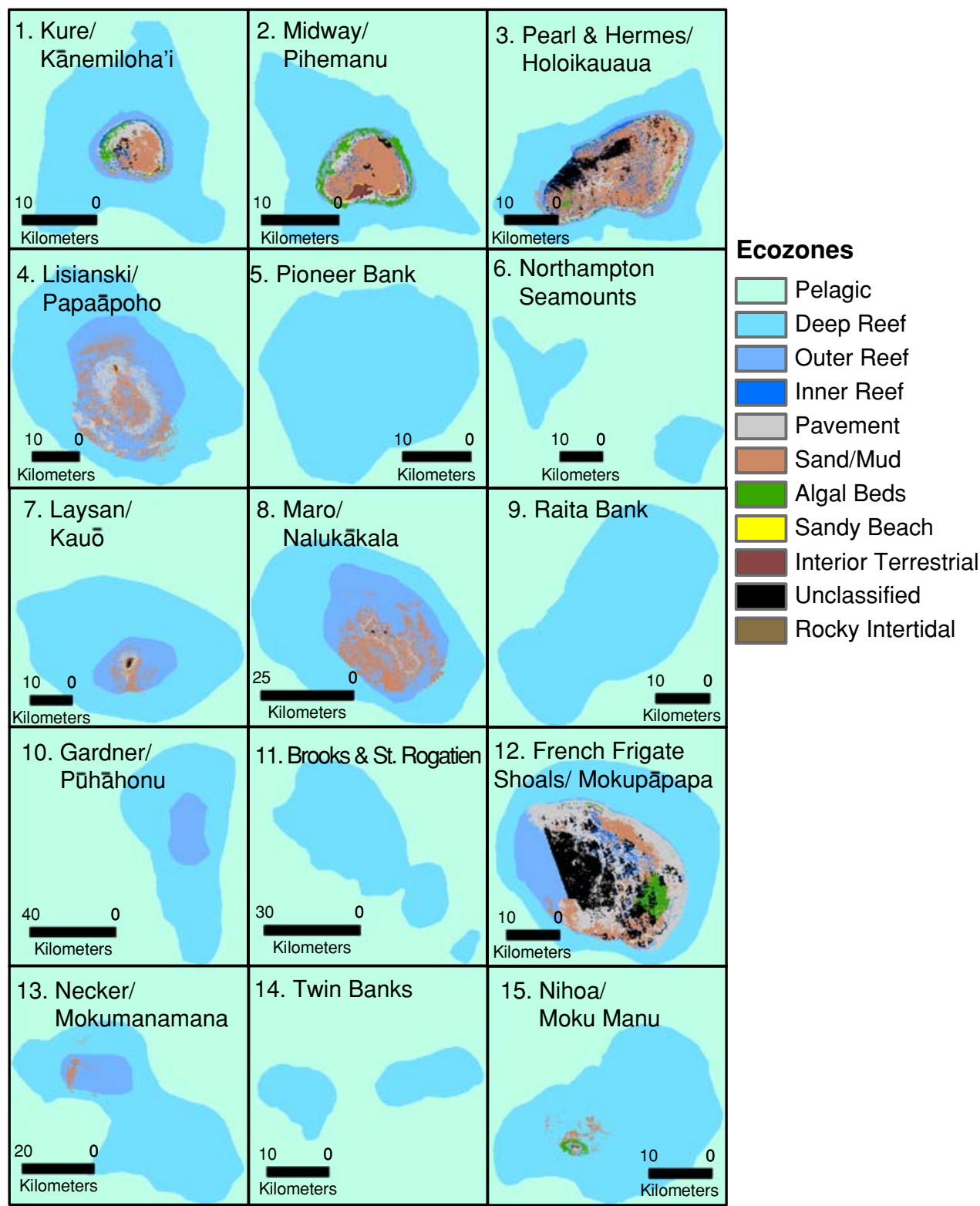

threats" by the conservation community and were the focus of the human activity data collection. In total, 24 distinct categories of recent potential anthropogenic threats were identified by experts (Selkoe et al. 2008) but spatial data for only 13 of them could be obtained or created; sea temperature rise was broken into two categories based on different calculations of temperature stress for a total of 14 threats considered here (Table 2). Of the missing 11 threats, four can be considered completely or almost completely inactive or insignificant at present in the Monument (aquarium collecting, sport fishing, recreation, and indigenous fishing). The other missing threats may have important impacts on the Monument ecosystems, most notably coastal engineering, chemical contamination, and ghost fishing (i.e., mortalities by lost nets), but also ship groundings, anchor damage, trampling damage, and pelagic fishing outside Monument boundaries. Details of the data sources and treatment for each of the threat layers used are included in the Electronic Supplementary Material 1.

\section{Vulnerability weights}

Many human activities have the potential to act as a threat to the ecological integrity of a marine ecosystem. These anthropogenic threats have different impacts depending on the ecological context of where they occur. For instance, ecological recovery from a ship grounding in a sandy bottom community will usually be faster than a ship grounding on a coral reef due to the slow growth rates of corals, making reefs more vulnerable to ship groundings than sandy bottom habitat. Here, vulnerability is defined as a combination of exposure and sensitivity and resilience, in 
Table 2 Summary of datasets used to make the cumulative impact map

\begin{tabular}{|c|c|c|c|c|c|}
\hline Threats & Resolution & Scale & Metric & Years & Data Source \\
\hline 1. Alien species & Atoll-level & Continuous & No. alien species observed & 2003 & Godwin et al. 2006 \\
\hline 2. Bottom fishing & 0.25 degree & Continuous & Pounds kept & 1996-2002 & DAR \\
\hline 3. Increased UV radiation & 1.0 degree & Continuous & No. positive anomalies & 1996-2004 & NASA \\
\hline 4. Lobster fishing & Atoll-level & Continuous & Mean fishing effort & 1983-1999 & Dinardo and Marshall 2001 \\
\hline 5. Marine debris ${ }^{\mathrm{a}}$ & $100 \mathrm{~m}$ & Continuous & No. debris recorded & 2000-2006 & CRED \\
\hline 6. Research diver impacts & $100 \mathrm{~m}$ & Binary & Presence of $1+$ diver & 2000-2006 & CRED \\
\hline 7. Research installations & $100 \mathrm{~m}$ & Binary & Presence of anchored equipment & 2004-2005 & CRED \\
\hline 8. Research wildlife sacrifice & $100 \mathrm{~m}$ & Binary & Site of wildlife collection & 2006 & CRED \\
\hline 9. Sea level rise & $100 \mathrm{~m}$ & Binary & Presence of water & N/A & Created \\
\hline 10. SST anomaly: bleaching & $4 \mathrm{~km}$ & Continuous & No. anomalies & 1985-2005 & NOAA \\
\hline 11. SST anomaly: disease & $4 \mathrm{~km}$ & Continuous & No. anomalies & 1985-2005 & NOAA \\
\hline 12. Seawater acidification & 1.0 degree & Continuous & Increase since 1870 & 2010 & Guinotte et al. 2003 \\
\hline 13. Ship-based pollution & $1 \mathrm{~km}$ & Continuous & No. ships & 2004 & Halpern et al. 2008 \\
\hline 14. Ship strike risk & $1 \mathrm{~km}$ & Continuous & No. ships & 2004 & Halpern et al. 2008 \\
\hline
\end{tabular}

$U V$ ultraviolet, SST sea surface temperature, CRED NOAA's Coral Reef Ecosystem Division of the Pacific Islands Fishery Science Center, DAR Hawai'i Division of Aquatic Resources

${ }^{a}$ Data only available for FFS, PH, Lisianski, Kure, Maro

keeping with the definition put forth by the Millennium Ecosystem Assessment (2005). With a workshop of conservation scientists and marine ecologists, Halpern et al. (2007) developed a suite of five criteria related to vulnerability to make basic characterizations of how activities impact ecosystems or ecozones differently: (1) the spatial scale at which the threat acts, (2) the frequency with which it acts, (3) the number of trophic levels impacted, (4) the resistance of the ecosystem to impact, and (5) the recovery time needed to return to an unimpacted state. Quantitative values for the five criteria were estimated from the mean of survey responses by 25 scientific experts on the NWHI and combined into a single "vulnerability score" for every ecozone-threat combination (Table 3; Selkoe et al. 2008). Two ecozones, subtidal sand and mud, and subtidal pavement, were not included in the original survey so vulnerability to threats was estimated separately by four appropriate experts from the first survey.

The cumulative impact model

The vulnerability scores were combined with spatial data on intensity of threats and maps of ecozones in a mathematical model to calculate the cumulative impact of threats for each $100 \mathrm{~m}$ grid cell of the Monument study domain. Each grid cell was assigned the dominant ecozone $(j)$ because of the small grid size, in contrast to other applications of this model at $1 \mathrm{~km}^{2}$ resolution, which allowed multiple ecosystem types per cell (Halpern et al. in press). Based on the data in Table 3, a vulnerability score $u_{i j}$ exists for every combination of threat type $i$ and ecozone type $j$. Continuous threat intensity data were $\log$ transformed and normalized to a $0-1$ scale. Transformed values for the intensity of each threat $D_{i}$ were associated with each grid cell. To translate threats into their ecological impacts, a weighted threat intensity $I_{D}$ was calculated as $D_{i} * u_{i j}$ based on the ecozone present in each grid cell. Cumulative impact scores $I_{C}$ were derived for each cell as of the sum of $I_{D}$ across all threats, such that $I_{c}=$ $\sum_{i=1}^{n} D_{i} * u_{i j}$, where $n=14$ total threats. Histograms displaying the frequency distribution of $I_{C}$ values (rounded to the first decimal place) at each atoll or bank were then generated. Ten equal bins between 0 and 20 were used for visualizing cumulative impact scores for ease of interpretation and simplicity (more bins add little detail; fewer bins mask important spatial heterogeneity).

Mean $I_{C}$ was calculated for several subsets of grid cells. Mean $I_{C}$ per atoll or bank included all grid cells within the outer boundary of deep reef for each atoll or bank. Mean $I_{C}$ per ecozone type included all cells of a ecozone regardless of location. These means were used to compare threats across atolls and ecozones in a way that controls for atoll or ecozone total area.

Threats were ranked by their summed impact, defined as the sum of $I_{D}$ across all grid cells, with the "worst" threat (rank 1) having the largest value. Threat footprints $(F)$ were also calculated as the total number of grid cells with positive values for that threat $\left(D_{i}>0\right)$, and are therefore total area calculations for each threat. Footprints have no incorporation of vulnerability scores or the intensity of the threat. Mean vulnerability scores were also calculated as weighted averages across ecozones, with weights derived as the total area of the ecozone in the Monument. 


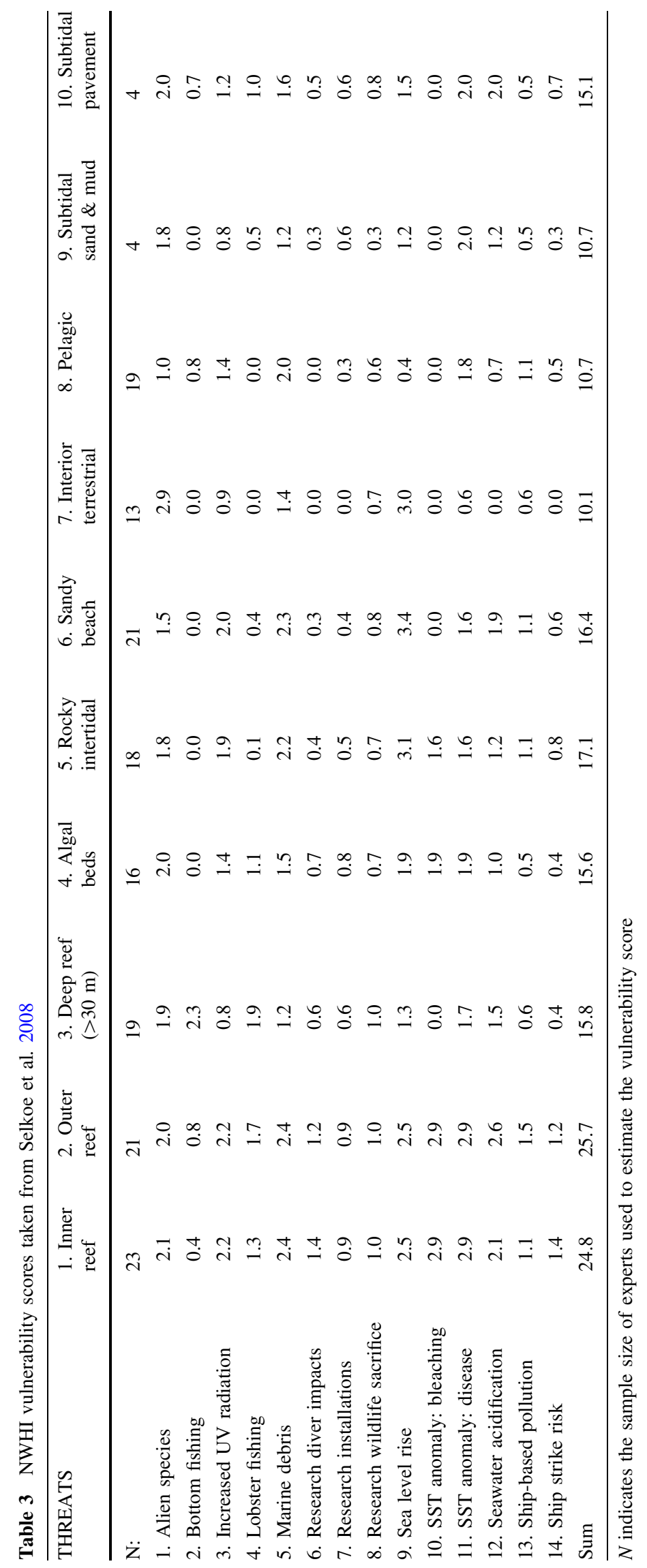


Sensitivity analyses

The particular combination of datasets available for this analysis could play a large role in the resulting pattern of cumulative impact, as could the quality of the datasets. Because the habitat mapping data are relatively highquality compared with what is available for most other areas of the oceans, the boundaries and classification of ecozones should not be a source of great error in the model. Therefore, sensitivity analyses of the resulting map to the input data focused on vulnerability scores and threat data as described below.

\section{Vulnerability score sensitivity}

There are three potential sources of error in the vulnerability scores: (1) they were obtained from the wrong expert pool, (2) the experts gave wrong answers, or (3) our method for calculating scores from expert judgment was incorrect. The first reason is unlikely as the expert pool represented the majority of people with first-hand scientific experience in the NWHI (Selkoe et al. 2008). The second reason is possible but unlikely; because only order-of-magnitude estimates for the five criteria are used, precise information from dedicated empirical research is generally not necessary, and the survey largely elicited broad consensus from the 25 experts on values for each threat by ecozone combination (Selkoe et al. 2008). Consequently, the sensitivity analysis focused on the third potential source of error.

The vulnerability score is sensitive to how the five criteria are combined into a single metric. In our original method, the five criteria were assumed to be equally weighted (Halpern et al. 2007; Selkoe et al. 2008), but recent analysis based on statistical analysis of experts' rankings of threats given assigned values for the five vulnerability criteria suggested otherwise. Instead, trophic impact and resistance drive expert judgment, independent of threats, ecosystems, or region of interest (Neslo et al. 2008). The unequal weighting derived from the Neslo et al. statistical analysis was as follows: $\quad($ spatial scale $* 0.06)+($ frequency $* 0.05)+$ $($ trophic impact $* 0.22)+($ resistance $* 0.67)+($ recovery time * 0.01), and the cumulative impact model was rerun with these modified vulnerability scores to examine the sensitivity of map results to the vulnerability score model.

\section{Threat data sensitivity}

The sensitivity of the results to particular data layers was assessed in several steps. First, the contribution of each driver data layer to the overall cumulative impact scores was assessed by running an impact model for each threat layer individually. The spatial correlations between the full model and each individual model were then calculated, and these correlations were compared among threats by the coefficient of determination $\left(R^{2}\right) . R^{2}$ describes the percent of variance explained by the correlation, providing an estimate of the degree to which the single layer contributes to the spatial patterns of the full model. In addition, the contribution of each driver data layer to the overall cumulative impact scores was assessed by leave-one-out resampling of the threat layers. Again, the $R^{2}$ values for the spatial correlations of leave-one-out models with the full cumulative impact model were used to assess the influence of each threat on the full model. Finally, the contribution of two categories of data, climate change components (threats numbered 3, 9, 10, 11, and 12 in Table 3) and non-climate change components (all others), to the final model were assessed by rerunning the model with these non-overlapping subgroups of threats and assessing spatial correlations of each to the whole model.

\section{Global model comparisons}

To test how comparable the results from these analyses were to results for the same region from the global-scale analyses, the global cumulative impact map of Halpern et al. (2008) was reprojected to match the projection of the NWHI model and clipped to the Monument boundaries (Fig. 1). The per-pixel values from the two models were regressed to quantify their spatial correlation with an ordinary-least squares (OLS) model. The strength of the correlation indicates how similar the models are despite very different data sources, resolution, and methodology of the two models. The models share only three of the 17 data layers used in the global analysis (threats numbered 3, 13 and 14 in Table 4).

There were several attributes of the global model that were known to represent the Monument poorly and could be easily modified to improve the global cumulative impact model for the Monument. A "quick-fix" version of the global model that incorporated these modifications was run and compared with the NWHI model using spatial correlation. Three specific changes were made to the global model to create the quick-fix model. First, ecosystem designations used in the global model were modified to match ecozone designations of the NWHI. Namely, ecosystems $>200 \mathrm{~m}$ depth were excluded, because they are poorly known in the NWHI and not included in the NWHIspecific model, and ecosystems not relevant to the NWHI were excluded (e.g., mangroves and seagrass). Second, the representation of atoll benthos was improved by designating areas called shallow soft bottom and rocky reef as pavement, because both were used arbitrarily for the same habitat type in the global model, and similarly, areas called hard shelf and soft shelf were both designated as deep reef (see Electronic Supplementary Material 2). Third, all 
Table 4 Vulnerability scores for the "quick-fix" version of the global model

\begin{tabular}{|c|c|c|c|c|c|c|c|c|}
\hline NWHI Threat & Global Threat & $\begin{array}{l}\text { Coral } \\
\text { Reefs }^{1}\end{array}$ & $\begin{array}{l}\text { Rocky } \\
\text { Reefs }^{2}\end{array}$ & $\begin{array}{l}\text { Soft shallow } \\
(<30 \mathrm{~m})^{2}\end{array}$ & $\begin{array}{l}\text { Hard shelf } \\
(30-200 \mathrm{~m})^{3}\end{array}$ & $\begin{array}{l}\text { Soft shelf } \\
(30-200 \mathrm{~m})^{3}\end{array}$ & Seamounts ${ }^{3}$ & $\begin{array}{l}\text { Pelagic waters } \\
(0-200 \mathrm{~m})^{4}\end{array}$ \\
\hline 1. Alien species & Species invasion & 0 & 0 & 0 & 0 & 0 & 0 & 0 \\
\hline 2. Bottom fishing & $\begin{array}{l}\text { Fishing: demersal, } \\
\text { non-destructive, high-bycatch }\end{array}$ & 0.4 & 0.8 & 0.8 & 2.3 & 2.3 & 2.3 & 0.8 \\
\hline 2. Bottom fishing & $\begin{array}{l}\text { Fishing: demersal, } \\
\text { non-destructive, low-bycatch }\end{array}$ & 0.4 & 0.8 & 0.8 & 2.3 & 2.3 & 2.3 & 0.8 \\
\hline 2. Bottom fishing & Fishing: pelagic, high-bycatch & 0.4 & 0.8 & 0.8 & 2.3 & 2.3 & 2.3 & 0.8 \\
\hline 2. Bottom fishing & Fishing: pelagic, low-bycatch & 0.4 & 0.8 & 0.8 & 2.3 & 2.3 & 2.3 & 0.8 \\
\hline $\begin{array}{l}\text { 3. Increased UV } \\
\text { radiation }\end{array}$ & UV & 2.2 & 2.2 & 2.2 & 0.8 & 0.8 & 0.8 & 1.4 \\
\hline $\begin{array}{l}\text { 11. SST anomaly: } \\
\text { disease }\end{array}$ & Sea temperature & 2.9 & 2.9 & 2.9 & 1.7 & 1.7 & 1.7 & 1.8 \\
\hline $\begin{array}{l}\text { 12. Seawater } \\
\text { acidification }\end{array}$ & Ocean acidification & 2.1 & 2.6 & 2.6 & 1.5 & 1.5 & 1.5 & 0.7 \\
\hline $\begin{array}{l}\text { 13. Ship-based } \\
\text { pollution }\end{array}$ & Ocean-based pollution & 1.1 & 1.5 & 1.5 & 0.6 & 0.6 & 0.6 & 1.1 \\
\hline 14. Ship strike risk & Commercial Shipping & 1.4 & 1.2 & 1.2 & 0.4 & 0.4 & 0.4 & 0.5 \\
\hline N/A & Nutrient input & 0 & 0 & 0 & 0 & 0 & 0 & 0 \\
\hline N/A & Nonpoint organic pollution & 0 & 0 & 0 & 0 & 0 & 0 & 0 \\
\hline N/A & Nonpoint non-organic pollution & 0 & 0 & 0 & 0 & 0 & 0 & 0 \\
\hline N/A & Direct Human & 0 & 0 & 0 & 0 & 0 & 0 & 0 \\
\hline N/A & Fishing: demersal, destructive & 0 & 0 & 0 & 0 & 0 & 0 & 0 \\
\hline N/A & Artisanal fishing & 0 & 0 & 0 & 0 & 0 & 0 & 0 \\
\hline N/A & Benthic Structures & 0 & 0 & 0 & 0 & 0 & 0 & 0 \\
\hline
\end{tabular}

NWHI Threat column indicates the closest matching NWHI-specific threat for each Global Threat; Global threats are taken from Halpern et al. 2008. Footnotes indicate the closest matching NWHI ecozone also used to provide the new vulnerability scores for the Global Threats; other ecosystems in the global model were excluded. Zeros indicate that global threat data had no positive values in the Monument boundaries

${ }^{1}$ Inner reef

2 Pavement

${ }^{3}$ Deep reef

${ }^{4}$ Pelagic

vulnerability weights were taken from the survey of NWHI experts instead of the global survey, which required matching the names of the NWHI list of threats with the most appropriate datasets in the global analysis, and matching the global ecosystem types with the most appropriate ecozone type, as indicated in Table 4. The net result of these changes was a new set of vulnerability scores with which to run the global model, using the original global threat data and global ecosystem data (albeit reclassified in some cases as explained above).

\section{Results}

\section{Spatial comparisons}

Cumulative impact scores ranged from 3.4 to 19.1 , with a mean of 4.5. The theoretical maximum possible score, given the vulnerability scores in Table 2, would be 25.7, based on all 14 threats occurring at their highest level in an outer reef grid cell. Because the majority of the area is pelagic water ( $94 \%$ of the cells) with low vulnerability and fewer threats, the great majority of pixels had low-cumulative impact scores (Fig. 3 panel a). The maximum observed score of 19.1 occurred at an inner reef location at Maro Reef. No single grid cell showed a zero value, due to the blanket coverage of the climate change threats. The blanket coverage of these threats also means that nowhere in the Monument was affected by fewer than three threats per cell, with an average of five (Fig. 3 panel b). The maximum observed number of threats per cell was 13 out of the 14 included, and occurred at Maro Reef; FFS and Pearl and Hermes showed a maximum of 12. However, Laysan showed the highest mean number of threats per cell (10.6). No fewer than six overlapping threats are present within the atolls but some of the banks have areas with as 
Fig. 3 a Map of cumulative impact for the

Papahānaumokuākea Marine binned into 10 equal bins from 0 to 20. b Map of cumulative human footprint. Scores represent the number of threats present per cell, without modification by vulnerability scores. Numbers correspond to atoll and bank names in Fig. 2 National Monument. Scores are

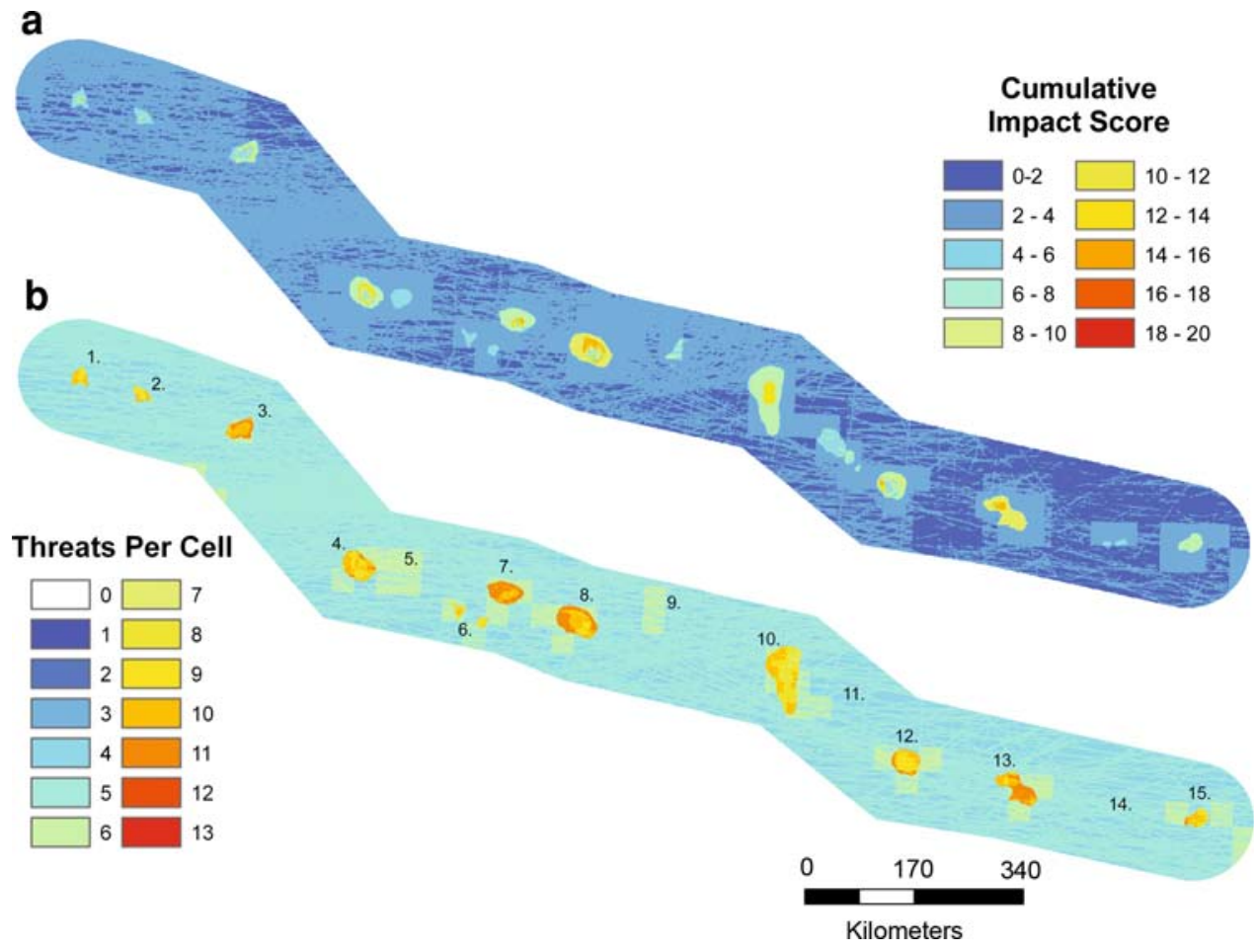

Comparisons across threats

few as four. In the pelagic waters, as many as seven overlapping threats occur, with a mean of 4.8.

Among the atolls and banks, there is heterogeneity in cumulative impact (Fig. 4). Averaged over all ecozones within the atolls, Maro Reef, had the highest mean cumulative impact score (11.3), due to shallow reef areas making up a large percentage of total area there. The banks have the lowest mean scores overall (6.8-7.9), and Kure Atoll and Midway Islands are the atolls with the lowest mean scores $(7.2,7.6)$. However, there are important threats at each atoll, even those with slightly lower mean scores. For instance, Midway atoll has the highest mean impact score for alien species and Pearl and Hermes has the highest scores for ship-based pollution and ship strike risk. Mean cumulative impact scores vary much more by ecozone type than across atolls. Outer reefs (making up $0.6 \%$ of the cells) had the largest mean cumulative impact scores (14.6), with inner reefs (only $0.02 \%$ of the cells; present at Kure, Midway, PH, Maro Reef, and FFS) tending to be only slightly less (13.8). No inner or outer reef cell showed a value $<11.0$. Cumulative impact scores in all other ecozones tended to be lower than in inner and outer reefs. Deep reefs (4\% of the cells) showed a large spread of values between 4.6 and 11.1. Scores in pelagic waters ranged 3.4-6.0 with a mean of 4.2. The other ecozones (algal beds, rocky intertidal, sandy beach, terrestrial, subtidal sand and mud, and pavement) make up the remaining $0.4 \%$ of the waters; their scores ranged 3.5-11.1, with terrestrial showing the lowest scores, partly due to a bias toward ocean-derived threat data.
Threats were compared in three ways: by the total size of their footprint, the vulnerability of the NWHI to the threats, and a combination of these two, which is their summed impact (Fig. 5). The data show that climate change threats have the largest footprints, covering the entire Monument, roughly 0.36 million $\mathrm{km}^{2}$. Ship-based pollution and ship strike risks cover $72 \%$ of the waters. Bottom fishing covers $18 \%$ and lobster trap fishing and alien species were both $\sim 0.4 \%$. Debris and the three research threats were very slight.

In the ranking of threats by summed impact, diseaserelated SST anomalies ranked first, followed by increased UV radiation and seawater acidification. Sea level rise and bleaching-related SST anomalies had smaller summed impact because the pelagic zone had low vulnerability scores associated with these threats; when the pelagic zone is excluded, they increase in ranking. The values for rankings by the weighted-average vulnerability scores across ecozones show a more uniform distribution across threats, with marine debris and the research threats showing comparable scores to some of the others because their small footprints are not considered in this ranking.

\section{Sensitivity analyses}

The vulnerability weights that resulted from the equal and unequal weighted combination of the mean values of the five vulnerability criteria were highly correlated 
Fig. 4 Cumulative impact scores for atolls, reefs, and banks. Scores are binned into 10 equal bins from 0 to 20

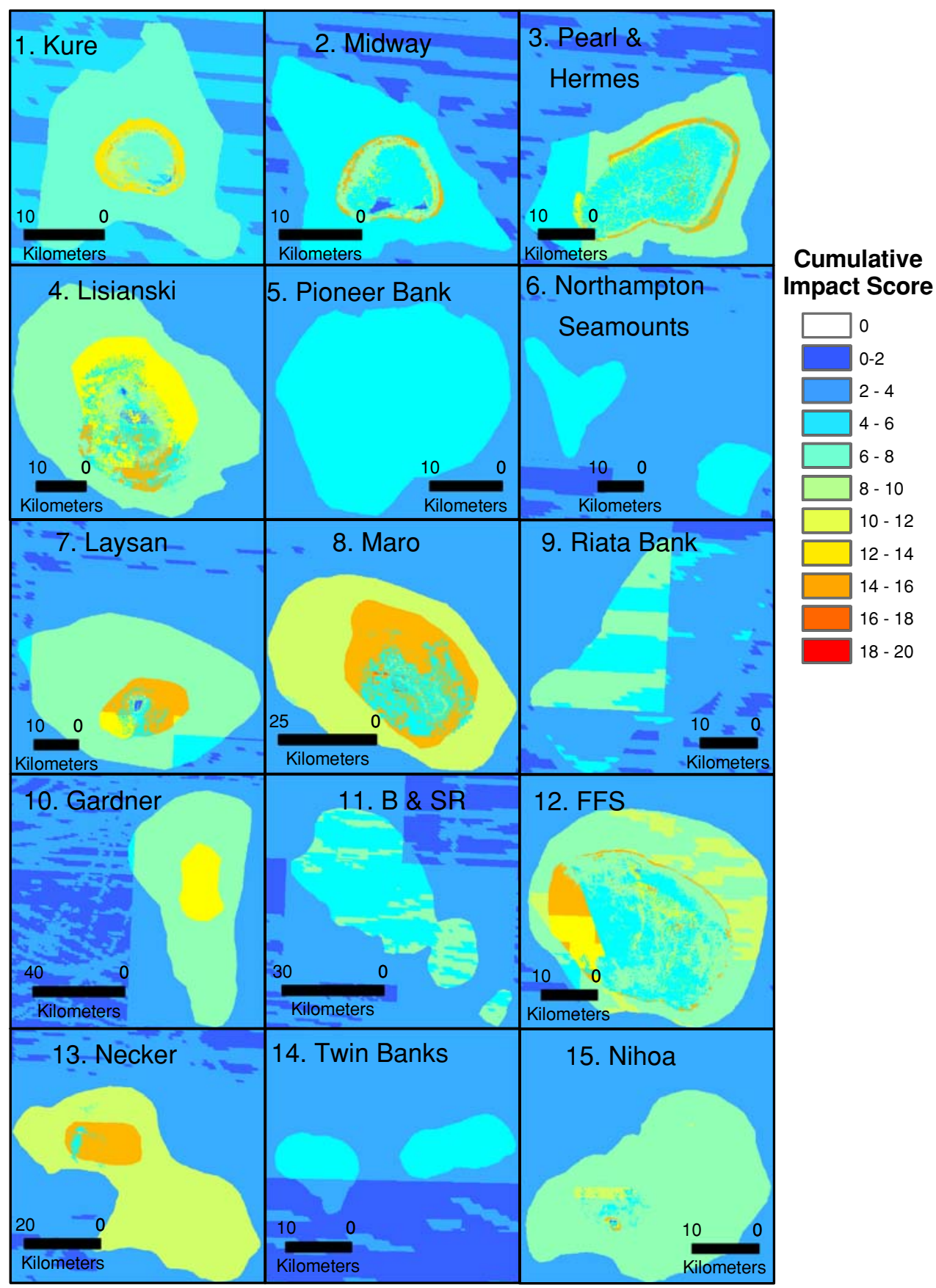

$\left(R^{2}=0.98\right)$. This high correlation stemmed, by chance, from the high correlation of resistance scores with the unweighted average vulnerability scores $\left(R^{2}=0.99\right)$ and the large weight given to resistance (0.67) in the unequal weighting model. Because of the high correlation between the two versions of the vulnerability scores, the maps that these sets of scores produced are nearly identical $\left(R^{2}=\right.$ 1.0, see Table 5) so the map made with the unequal weighting model is not shown.

Examination of how each data layer correlated with the cumulative impact map revealed that seawater acidification, sea level rise and lobster fishing were strongly correlated with the full model (Table 5). Spatial coverage of data influenced the correlation, as scarce threats like research and marine debris showed low correlations. However, the UV, ship-based pollution and ship strike risk data layers, which had high $(1 \mathrm{~km})$ resolution and complete or near coverage of the study area, had almost no correlation with the final results (Table 5). The leave-one-out resampling models showed uniformly high correlations with the full model $\left(0.95<R^{2}<1.00\right)$. Removing the bottom fishing layer had the largest effect on 
Fig. 5 Ranking of threats by their summed impact (sum of impact scores across all pixels), footprint (number of pixels impacted), and vulnerability (weighted average across ecozones by relative area). Values are expressed relative to the maximum observed. Left panel: all ecozones included; right panel: pelagic ecozone excluded

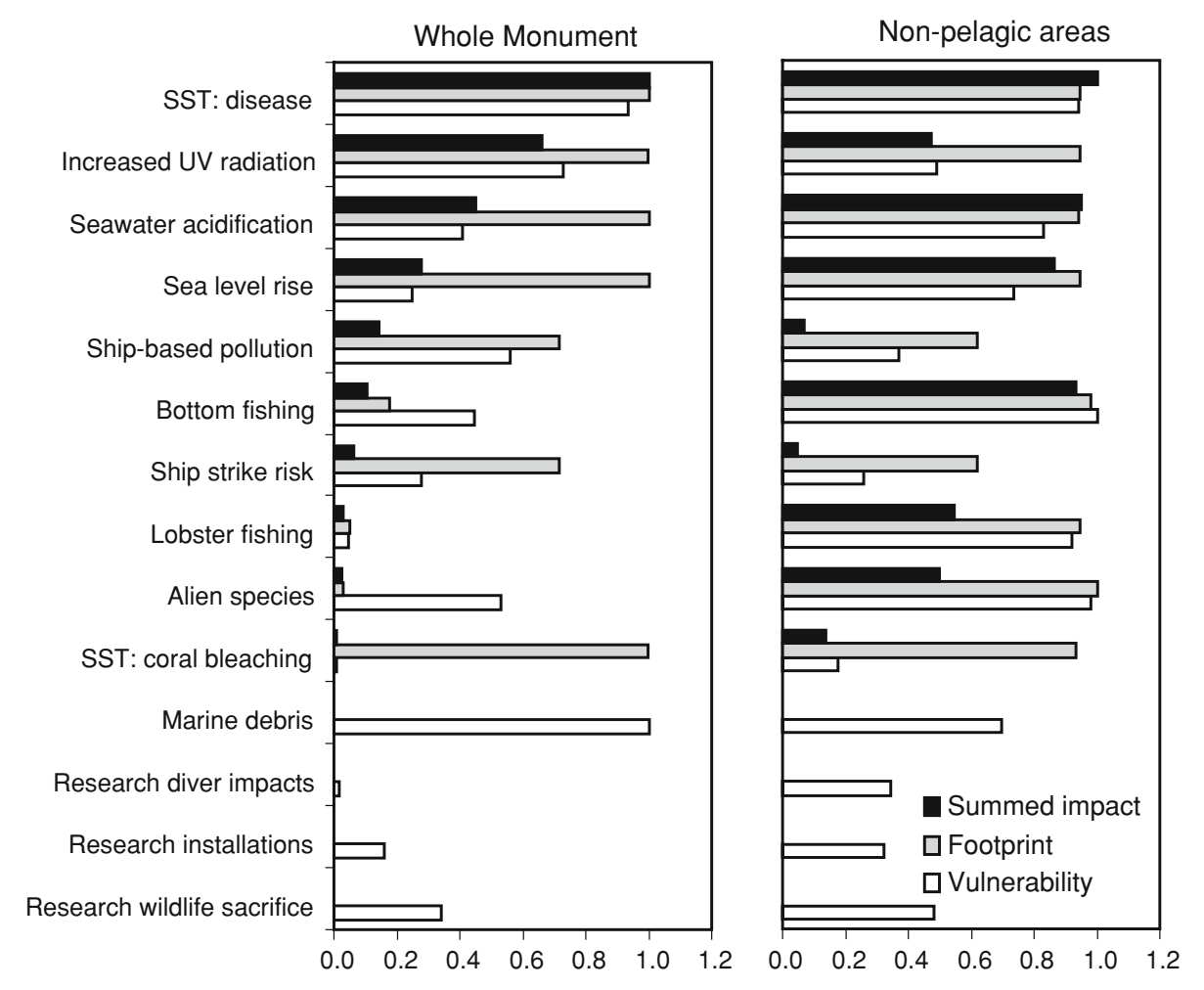

the model $\left(R^{2}=0.95\right)$. All other resampled models showed roughly equivalent correlation of $R^{2}=0.99-1.00$ with the full model.

When only climate change data were used in the model, the spatial pattern was not grossly different on average from the full model $\left(R^{2}=0.83\right.$ for the two models; Table 5). Disease-related thermal anomaly patterns peaked at the northwest end of the chain, coral bleaching probabilities peaked at both ends of the chain and increased UV radiation and seawater acidification tended to have high values at the center of the chain (Fig. 6 panels a-d). Pearl and Hermes stands out among the atolls as having the highest mean impact scores for both SST anomaly metrics, despite the fact that Maro reef has the largest amount of shallow reef environment. All banks, Nihoa, Necker, and Gardner, have low-mean impact scores for most climate change threats because they are dominated by deep water areas with lower vulnerability.

When climate change threats were excluded from the cumulative impact model, the spatial correlation with the full model is also high $\left(R^{2}=0.89\right)$, but the pattern is different (Fig. 6 panel e). Heterogeneity in the pelagic waters due to ship tracks becomes pronounced and apparent shipping lanes at the northwest edge of the Monument and between Pearl and Hermes and Lisianski caused high scores there (Fig. 6 panel e). Bottom fishing is the other dominant impact in the pelagic areas surrounding banks (where fishing is actually concentrated) because of the low resolution of the fishing data. The atolls appear to have uniformly high scores relative to the full range of scores in this model, but there is, in fact, some small scale heterogeneity in scores within and among atolls, mostly because of the spatial patterns of bottom fishing, lobster fishing, and alien species impacts (Fig. 6 panel f).

Global versus NWHI models

In contrast to the original global model results (Fig. 1), the NWHI-specific model shows impact scores with greater values within atolls compared with the pelagic waters (Fig. 3 panel a) because of the more accurate habitat maps and more appropriate datasets. Consequently, there is no spatial correlation of scores for these two models $\left(R^{2}=0.01\right.$, Table 5). With these differences largely accounted for, the 'quick-fix' global model looks more similar to the NWHI-specific model (Fig. 7), and indeed shows a much higher spatial correlation $\left(R^{2}=0.59\right.$, Table 5$)$.

\section{Discussion}

\section{The NWHI model results}

Despite its protected status and remote location, the NWHI is significantly affected by more than a dozen human activities. The worst impacts are those related to climate change, resulting primarily from human activities elsewhere. These top threats contrast with results for coral reefs 
Table 5 Summary statistics describing the distribution of impact scores for each model run and the coefficient of determination $\left(R^{2}\right)$ for the correlation of each model with the NWHI full cumulative impact model

\begin{tabular}{|c|c|c|c|c|c|c|}
\hline & Min. & Max. & Mean & SD & Sum & $\overline{R^{2} \text { with full model }}$ \\
\hline \multicolumn{7}{|l|}{ NWHI cumulative models } \\
\hline Full cumulative impact model & 3.4 & 19.1 & 4.5 & 1.27 & $162,340,583$ & 1.00 \\
\hline Modified vulnerability score model & & & & & $162,340,583$ & 1.00 \\
\hline Climate change data only & 3.4 & 12.4 & 3.9 & 0.66 & $140,761,404$ & 0.83 \\
\hline Excluding climate change data & 0.0 & 7.4 & 0.7 & 0.83 & $21,579,179$ & 0.89 \\
\hline Excluding research data & 3.4 & 17.6 & 4.5 & 1.27 & $162,340,382$ & 1.00 \\
\hline \multicolumn{7}{|l|}{ Single threat models } \\
\hline 1. Alien species & 0.0 & 2.1 & 0.0 & 0.25 & $1,544,620$ & 0.75 \\
\hline 2. Bottom fishing & 0.0 & 2.3 & 0.2 & 0.44 & $6,225,223$ & 0.73 \\
\hline 3. Increased UV radiation & 0.0 & 2.1 & 1.1 & 0.17 & $38,841,509$ & -0.10 \\
\hline 4. Lobster fishing & 0.0 & 1.9 & 0.0 & 0.25 & $1,688,010$ & 0.81 \\
\hline 5. Marine debris ${ }^{\mathrm{a}}$ & 0.0 & 2.4 & 0.0 & 0.01 & 3,608 & 0.06 \\
\hline 6. Research diver impacts & 0.0 & 1.4 & 0.0 & 0.00 & 151 & 0.01 \\
\hline 7. Research installations & 0.0 & 0.9 & 0.0 & 0.00 & 28 & 0.01 \\
\hline 8. Research wildlife sacrifice & 0.0 & 1.0 & 0.0 & 0.00 & 22 & 0.00 \\
\hline 9. Sea level rise & 0.4 & 3.4 & 0.5 & 0.25 & $16,411,242$ & 0.93 \\
\hline 10. SST anomaly: bleaching & 0.0 & 2.8 & 0.0 & 0.15 & 430,351 & 0.59 \\
\hline 11. SST anomaly: disease & 0.5 & 2.9 & 1.6 & 0.13 & $58,702,214$ & 0.31 \\
\hline 12. Seawater acidification & 0.0 & 2.6 & 0.7 & 0.21 & $26,376,088$ & 0.93 \\
\hline 13. Ship-based pollution & 0.0 & 1.0 & 0.2 & 0.18 & $8,296,637$ & 0.06 \\
\hline 14. Ship strike risk & 0.0 & 0.7 & 0.1 & 0.08 & $3,820,881$ & 0.12 \\
\hline \multicolumn{7}{|l|}{ Global models } \\
\hline Original global summed model & 0.5 & 9.5 & 3.2 & 0.36 & $114,379,979$ & 0.01 \\
\hline Quick-fix model & 0.0 & 14.0 & 3.1 & 0.57 & $46,095,926$ & 0.59 \\
\hline
\end{tabular}

globally, for which overfishing, coastal development, and pollution are deemed greater or at least equally important threats to climate change impacts (Kleypas and Eakin 2007). Because many threats could not be included here for lack of available spatial data, the levels of impact suggested here are conservative.

There were three distinct groups of data as categorized by their impact scores, footprints, and vulnerability scores. (1) Climate change threats have the largest footprints, large average vulnerability scores and affect the entire area. (2) Research threats (diving, sacrifice, and installations) have small average vulnerability scores and footprints. Because they affect less than $15 \mathrm{~km}^{2}$ total, equivalent to $0.001 \%$ of the atoll and bank area in the NWHI (which themselves make up $5.1 \%$ of the Monument waters), research threats could be considered negligible. (3) Four threats occur at large scales with moderate impact and affect the majority (60-90\%) of the atoll and bank waters: bottom fishing, lobster fishing, alien species, and the two shipping threats. At present, the only threats in this latter category that can be managed are shipping, because lobster fishing has ceased, the last bottom fishing remaining will cease by 2011, and alien species are almost impossible to remove.
Shipping includes associated risks of alien species introductions, grounding, pollution, anchor damage, faunal strikes, and illegal fishing; consequently, the managers of the Monument have acted quickly to restrict shipping and instituted a rigorous permitting process for non-transit shipping. Marine debris should also be in the latter category, but was underrepresented here. Debris can be, and currently is, managed by removal.

Because the climate change datasets have positive values for all grid cells, they lead to the conclusion that the archipelago has no unimpacted, pristine areas. Although anthropogenic climate change effects are ubiquitous, they are often overlooked because impacts are gradual and hard to measure. Increased SST anomalies induced by recent climate change may have caused bleaching and disease events that have decreased coral cover throughout the NWHI. Several studies have documented large bleaching events associated with unusually high SSTs during El Niño conditions (Aeby et al. 2003; Kenyon and Brainard 2006). While coral cover in the NWHI is naturally low (Vroom et al. 2005), there has also been, most likely, a recent decline, as suggested for both the Hawaiian archipelago specifically and the tropical Pacific generally (Bruno et al. 


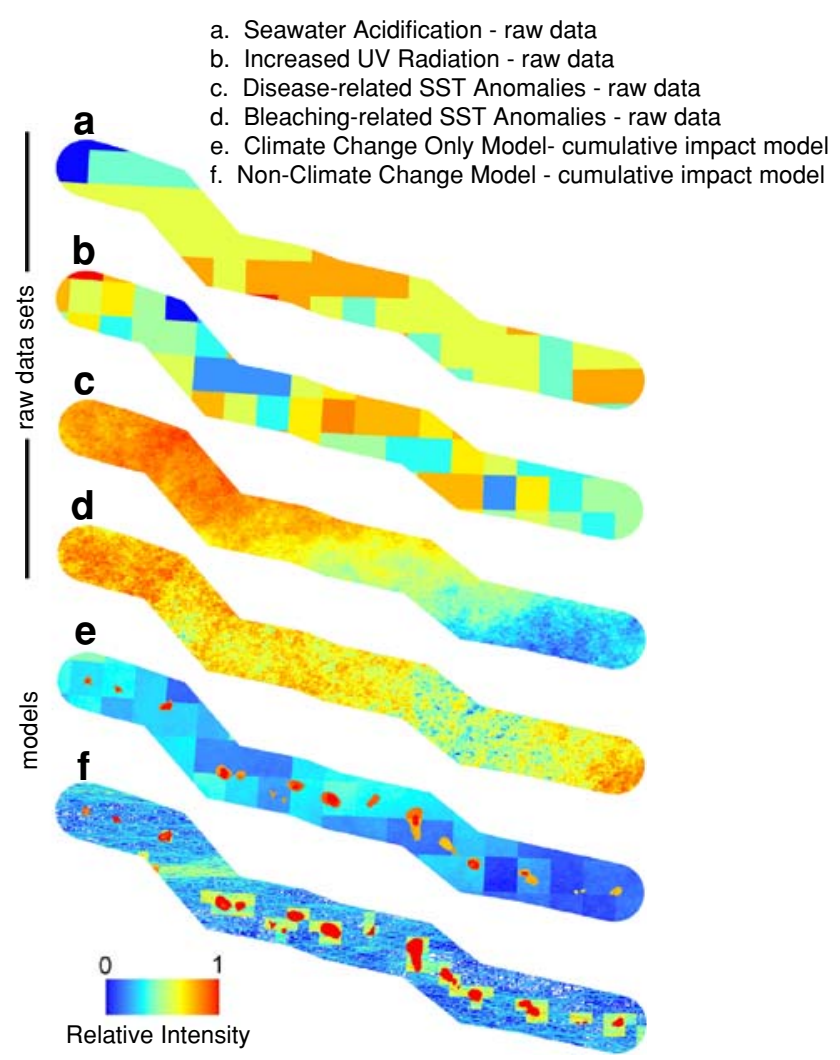

Fig. 6 Selected data relevant to climate change impacts. Panels a-d represent raw data layers, and panels e and $f$ are cumulative impact models using just the climate and non-climate datasets

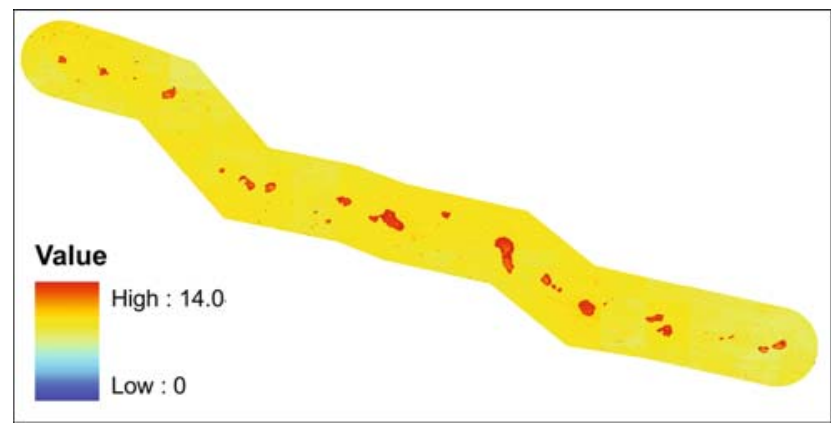

Fig. 7 Cumulative impact map according to the "quick-fix" version of the global model

2007). The impacts of SST changes on other aspects of the NWHI ecosystem are harder to estimate because of lack of baseline data and difficulty in monitoring. Evidence from the Great Barrier Reef (GBR) suggests that recent decrease in foraging and hatchling success of sooty terns, a species also important to the NWHI, is related to increased SST variability (Erwin and Congdon 2007). The impacts of seawater acidification are even less well known, but mesocosm experiments predict substantial losses of organic carbon from the upper layers (Riebesell et al. 2007) and loss of accretion rates for crustose coralline algae and other calcifying organisms including reef-building corals (Jokiel et al. 2008, Kuffner et al. 2008). Even slight impacts on the zooplankton in the pelagic zone in the NWHI could have large trophic effects given the sensitivity of bird, mammal, and turtle species that depend on the pelagic food web. Evidence that coral accretion rates have already slowed in recent decades from acidification already exists for the GBR (Cooper et al. 2008). Although warming seawater could have some positive effects for higher latitude reefs, the negative effects of acidification are expected to dominate (Guinotte et al. 2003; Hoegh-Guldberg et al. 2007). Future comparison of in situ data on bleaching, disease and effects of acidification to these remotely sensed data would be useful in further validating their accuracy at smaller scales and investigating their impacts.

Regional-scale analysis

The NWHI is a unique ecosystem in a highly unusual human context. Not surprisingly, the spatial pattern of cumulative impacts from this regional analysis contrasts significantly with the results for the NWHI from the globalscale analysis (Halpern et al. 2008), for several reasons. First, the global pool of experts assigned high vulnerability to the deeper hard bottom areas, because when they are associated with continental shelves they are often impacted by a variety of human activities (e.g., frequency of threat exposure is far greater). Second, the reef areas show up as pristine in the global model because these areas were generally incorrectly identified as soft-sediment habitat, which had very low vulnerability scores. The global model also lacked datasets on fishing, alien species, and other threats important to the NWHI atolls. Instead, it focused on land-based pollution, coastal development and coastal population effects that are dominant threats in the main Hawaiian Islands and elsewhere. Importantly, these contrasts highlight the great difference in the on-going anthropogenic threat between reefs in the NWHI and the main Hawaiian Islands, and the value of NWHI-specific research and monitoring. Poor performance of the global model for the NWHI does not predict poor performance elsewhere. For instance, a total re-analysis of the west coast of the US and Baja California, Mexico, using the same approach here and similarly low overlap in data sources with the global study, produced a spatial correlation between the global model and the new model $>92 \%$ (Halpern et al. in press).

The quick-fix method is one way to improve the global model, but remains inferior to the NWHI-specific model because of its shortened list of threats and poor quality habitat data. Its value is simply in demonstrating to what extent the global data can be manipulated to improve the representation of cumulative impacts in the Monument. 
This approach may be adequate for many regional-scale analyses (depending on the management needs) on coarse scales if (1) global ecosystem data for the area seems fairly accurate, (2) top threats are represented by the global-scale list of data, and (3) new vulnerability scores can be obtained.

The sensitivity results for the NWHI-specific model suggest that vulnerability estimates are an important driver of the results, as many of the threat layers with fairly uniform distributions of intensity showed high correlation with the full model. This implies that accurate vulnerability scores and habitat data are both important. In this case, the habitat data came from NOAA maps that have their own set of gaps and caveats (e.g., the habitat classification scheme may have flaws), but are the best available and attain uncommonly high resolution at least in areas $<12 \mathrm{~m}$ depth. It is more difficult to scrutinize the sensitivity of the model results to the quality and coverage of the threat data. However, when many threat data layers with high coverage are used together, the model sensitivity to any one of them is diminished. The high correlations of both the climate change only, and non-climate change sub-model runs with the full model, suggest that the model is not highly sensitive to missing data. Many of the model runs with individual datasets also showed high correlation to the full model, likely due to the co-variation produced by the signal of ecozone variability. The model appeared most sensitive to the bottom fishing data, likely because of its unique patch sizes and locations and the high vulnerability associated with this threat. Using the unabridged (but classified) bottom fishing data (with catch from quadrants with $<3$ boats reported) would be an important improvement to the cumulative impact map. Of course, the fine scale patterns of impact within ecozones and atolls are more sensitive to the threat data quality and coverage but are difficult to assess.

Data gaps and data quality issues for maps of human activities and stressors are ubiquitous in marine systems, and it is crucial to assess how they might create bias or error in the cumulative impact map. The greatest data gap here occurred for marine debris; even at atolls where some data exist the coverage is scarce. The likely result is a substantial underestimation of the true impacts of marine debris. Other notable quality issues include alien species data, which overestimate distribution, and lobster fishing data, for which high-resolution data do not exist. However, choosing an atoll-level scale for alien species and lobster fishing impacts is appropriate given the diffuse effects of these impacts and that population structure occurs at the atoll-scale or larger for many NWHI species (e.g., Rivera et al. 2004).

Several key threats were missing from the model. In the past four decades, at least nine ship groundings have occurred in the NWHI, with associated Lyngbya (a genus of toxic cyanobacteria) outbreaks, reef destruction, oil spills, and debris contaminations (Gulko 2002). These ship groundings were not included here because exact coordinates were unavailable. Also unavailable were maps of toxic contamination from waste storage during military occupancy of FFS, Midway, and Kure which left behind lead, DDT, and PCBs. Despite removal and clean up of waste, elevated levels of toxics are present in tissue of marine organisms at these areas (Hope and Scatolini 2005). Moreover, significant levels of certain contaminants, such as copper and nickel, are also found in other areas of the NWHI, suggesting atmospheric deposition of chemicals is an important threat (Iwata et al. 1994). Coastal engineering was not included but primarily concerns the dredging, seawalls, and other modifications to Midway Harbor, Kure, and Tern Island at FFS. Trampling and recreation are also limited to these locations, and currently occur infrequently. Nevertheless, lingering effects are potentially important to those locations. Annual estimated visitors to Midway in 1997 was 5,000, with 160 residents (Gulko et al. 2002), some of them associated with a recreational fishing operation. Despite these data gaps, this regional analysis is one of the most comprehensive to date, includes the great majority of immediate threats to the area, and the threats associated with highest ecological vulnerability (Selkoe et al. 2008).

The cumulative impacts framework

The cumulative impact score is an index or an aggregation of many parameters used to summarize large amounts of data and measure trends. It takes the most common form of indices, a weighted arithmetic mean of subindices (i.e., threats) (Ott 1978). As such, the formulation of the cumulative impact score is meant to be transparent and straightforward to allow examination of how the scores result. The model attempts to move beyond simplistic focus on threat footprints, because footprints do not capture the importance of ecological context in determining the severity of threat impacts. To incorporate an ecosystem perspective, the threat intensities are weighted by a vulnerability score that accounts for the variable impact of threats depending on the habitat in which the footprint falls. The vulnerability scores could be derived in several ways, and here a survey of 25 experts was used to estimate relative vulnerability based on a standardized set of criteria, an approach appropriate for complex, uncertain situations where explicit empirical data is not available (Halpern et al. 2007).

By summing across threats, the cumulative impact model fails to account for possible synergisms and antagonisms among threats that may amplify or reduce the local 
cumulative impact. If synergisms are important, the differences in the ecological condition between sites with low scores/few threats and sites with high scores/many threats are likely larger than the model would suggest. Accounting for synergisms in the cumulative impact model is not straightforward because not all threat combinations produce synergisms and little information exists on how synergisms change as threats accumulate (Crain et al. 2008). Nevertheless, synergisms are predicted to be important to the future health of coral reefs (HoeghGuldberg et al.2007).

Accounting for ecological dynamisms, such as feeding and spawning migrations by turtles, sea birds, mammals, and pelagic fishes are another challenge to mapping the ecological impacts of human activities accurately. In this analysis, these spatial linkages, which effectively expand the spatial extent of threat impacts, are partially accounted for in the vulnerability weight by the "spatial scale" criterion (Selkoe et al. 2008). However, these expansions of impact could also be mapped by incorporating maps of where species occur. This approach might also allow for better accounting of species-specific issues in the cumulative impact model, such as required by the Endangered Species Act.

Because historical impacts are largely unaccounted for, the scores represent present day overall stress on the ecosystem and not a measure of overall condition or health. Some less visited places, like Maro Reef, had high scores because of large percentages of shallow reef habitat. Midway, which is widely reported to have the most visible signs of degradation today and the longest history of intense use, did not show up as one of the sites of greatest impact in this analysis because of the historical impacts important to Midway (e.g., overfishing, chemical contamination, dredging) were unaccounted for here. Evidently, Midway's biota has yet to fully recover from these historical impacts, which were discontinued, in some cases, decades ago. In this analysis, these lingering impacts were not considered on-going stressors in the way that current levels of climate change, shipping, and other activities were. Combining historical spatial threat data with the current threat data synthesized here would enable creation of a metric approximating ecological "health," condition or degradation.

Integration with management plans

Even without translation into an index of ecological health, the relative cumulative impact scores aid in making spatial comparisons that integrate across many diverse types of information. The threat ranking and mapping products from this project represent a summarized, synthetic view of how the ecosystem as a whole experiences human uses of the NWHI. The quality of the results depends on the quality of the input data. Some basic applications of these maps are to aid in decisions on where to permit new activities, where to monitor climate change impacts, and as a catalog of data for the region. The site-specific cumulative impact scores can be factored into other spatial decision-making tools, such as MARXAN (Stewart et al. 2003), to include an optimal number of low or high impact sites in specific management subregions. While ecological effects are central to management decision-making, many other topics come into play, such as economics, governance, and cultural values. The cumulative impact model could easily be modified to include vulnerability weights based on factors other than ecological vulnerability. Combining the cumulative impact map with different types of data and keeping it updated will maximize its use as a flexible management tool.

Acknowledgments Thanks to the Northwestern Hawaiian Islands scientific and management communities for their participation and data sharing. Thanks to Rusty Brainard for help with benthic cover data, the Marine Debris Team at the NOAA PIFSC Coral Reef Ecosystem Division, and John Guinotte for assistance with acidification data. Funding was provided through a National Marine Sanctuaries MOA 2005-008/66832 (KAS and RJT) and the David \& Lucille Packard Foundation and NCEAS (BSH).

Open Access This article is distributed under the terms of the Creative Commons Attribution Noncommercial License which permits any noncommercial use, distribution, and reproduction in any medium, provided the original author(s) and source are credited.

\section{References}

Aeby GS, Kenyon JC, Maragos JE, Potts DC (2003) First record of mass coral bleaching in the Northwestern Hawaiian Islands. Coral Reefs 22:256 256

Balazs GH, Chaloupka M (2004) Recovery trend over 32 years at the Hawaiian green turtle rookery of French Frigate Shoals. Atoll Res Bull 543:147-158

Bruno JF, Selig ER, Casey KS, Page CA, Willis BL, Harvell CD, Sweatman H, Melendy AM (2007) Thermal stress and coral cover as drivers of coral disease outbreaks. PLoS Biology 5:1220-1227

Bryant D, Burke L, McManus JW, Spalding M (1998) Reefs at risk: a map-based indicator of threats to the world's coral reefs. World Resources Institute, Washington, DC

Cooper TF, De'Ath G, Fabricius KE, Lough JM (2008) Declining coral calcification in massive Porites in two nearshore regions of the northern Great Barrier Reef. Global Change Biol 14:529-538

Crain CM, Kroeker K, Halpern BS (2008) Interactive and cumulative effects of multiple human stressors in marine systems. Ecol Lett 11:1304-1315

Crowder LB, Osherenko G, Young OR, Airame S, Norse EA, Baron N, Day JC, Bouvere F, Ehler CN, Halpern BS, Langdon SJ, McLeod KL, Ogden JC, Peach RE, Rosenberg AA, Wilson JA (2006) Sustainability—resolving mismatches in US ocean governance. Science 313:617-618 
DiNardo GT, Marshall GJ (2001) Status of lobster stocks in the Northwestern Hawaiian Islands, 1998-2000. Southwest Fisheries Science Center Admin Rpt H-01-04, Honolulu, pp 1-31. http://www.pifsc.noaa.gov/adminrpts/2000-present/SWFC_Admin_ Report_01-04.pdf

Erwin CA, Congdon BC (2007) Day-to-day variation in sea-surface temperature reduces sooty tern Sterna fuscata foraging success on the Great Barrier Reef, Australia. Mar Ecol Prog Ser 331:255-266

Friedlander AM, DeMartini EE (2002) Contrasts in density, size, and biomass of reef fishes between the northwestern and the main Hawaiian Islands: the effects of fishing down apex predators. Mar Ecol Prog Ser 230:253-264

Friedlander A, Aeby G, Brainard R, Clark A, DeMartini E, Godwin S, Kenyon J, Kosaki R, Maragos J, Vroom P (2005) The state of coral reef ecosystems of the Northwestern Hawaiian Islands. In: Waddell $\mathbf{J}$ (ed) The state of coral reef ecosystems of the United States and Pacific Freely Associated States: 2005. NOAA Technical Memorandum NOS NCCOS 11. NOAA/NCCOS Center for Coastal Monitoring and Assessment's Biogeography Team, Silver Spring, pp 270-311

Godwin S, Rodgers KS, Jokiel PL (2006) Reducing potential impact of invasive marine specie in the Northwestern Hawaiian Islands National Marine Monument. In: Administration NHIMNM (ed) Coral Reef Assessment and Monitoring Program, Honolulu, HI http://www.fedworld.gov/onow

Guinotte JM, Buddemeier RW, Kleypas JA (2003) Future coral reef habitat marginality: temporal and spatial effects of climate change in the Pacific basin. Coral Reefs 22:551-558

Gulko D (2002) Vessel groundings in Hawaii: threats and impacts to nearshore coral reef ecosystems. Proceedings of the US Pacific Flag Islands Vessel Groundings Workshops, January and February, 2002. National Ocean Service, NOAA, and the Pacific Basin Development Council, pp 110-129

Gulko D, Maragos J, Friedlander A, Hunter CL, Brainard R (2002) The status of coral reefs in the Hawaiian archipelago. In: Wilkinson CR (ed) Status of coral reefs of the world: 2002. Australian Institute of Marine Science, Townsville, p 327250

Halpern BS, Selkoe KA, Micheli F, Kappel CV (2007) Evaluating and ranking the vulnerability of marine ecosystems to anthropogenic threats. Conserv Biol 21:1301-1315

Halpern BS, Walbridge S, Selkoe KA, Kappel CV, Micheli F, D’Agrosa C, Bruno JF, Casey KS, Ebert C, Fox HE, Fujita R, Heinemann D, Lenihan HS, Madin EMP, Perry MT, Selig ER, Spalding M, Steneck R, Watson R (2008) A global map of human impact on marine ecosystems. Science 319:948-952

Halpern BS, Kappel CV, Selkoe KA, Micheli F, Ebert C, Kontgis C, Crain CM, Martone R, Shearer C, Teck SJ (in press) Mapping cumulative human impacts to California Current marine ecosystems. Conserv Lett

Harrison CS (1990) Seabirds of Hawaii: natural history and conservation. Cornell University Press, Ithaca

Heinemann D, Gillelan H, Morgan L (2005) Bottomfishing in the northwestern Hawaiian Islands: is it ecologically sustainable? Marine Conservation Biology Institute, Bellevue, WA, pp 1-41. http://www.mcbi.org/what/what pdfs/nwhi bottomfish.pdf

Hoegh-Guldberg O, Mumby PJ, Hooten AJ, Steneck RS, Greenfield P, Gomez E, Harvell CD, Sale PF, Edwards AJ, Caldeira K, Knowlton N, Eakin CM, Iglesias-Prieto R, Muthiga N, Bradbury RH, Dubi A, Hatziolos ME (2007) Coral reefs under rapid climate change and ocean acidification. Science 318:1737-1742
Hope BK, Scatolini S (2005) DDT, DDD, and DDE in abiotic media and near-shore marine biota from Sand Island, Midway Atoll, North Pacific Ocean. Bull Environ Contam Toxicol 75:554-560

Iwata H, Tanabe S, Sakai N, Tatsukawa R (1994) Geographical distribution of persistent organochlorines in air, water and sediment from Asia and Oceania, and their implications for global redistribution from lower latitudes. Environ Pollut 85:15-33

Jokiel PL, Rodgers KS, Kuffner IB, Andersson AJ, Cox EF, Mackenzie FT (2008) Ocean acidification and calcifying reef organisms: a mesocosm investigation. Coral Reefs 27:473-483

Kenyon J, Brainard R (2006) Second recorded episode of mass coral bleaching in the Northwestern Hawaiian Islands. Atoll Res Bull 543:505-524

Kenyon JC, Vroom PS, Page KN, Dunlap MJ, Wilkinson CB, Aeby GS (2006) Community structure of hermatypic corals at French frigate shoals, Northwestern Hawaiian Islands: capacity for resistance and resilience to selective stressors. Pac Sci 60:153-175

Kleypas JA, Eakin CM (2007) Scientist's perceptions of threats to coral reefs: results of a survey of coral reef researchers. Bull Mar Sci 80:419-436

Kuffner IB, Andersson AJ, Jokiel PL, KuS Rodgers, Mackenzie FT (2008) Decreased abundance of crustose coralline algae due to ocean acidification. Nature Geoscience 1:114

Millennium Ecosystem Assessment (2005) Ecosystems and human well-being: biodiversity synthesis. World Resources Institute, Washington, DC

Neslo R, Micheli F, Kappel CV, Selkoe KA, Halpern BS, Cooke RM (2008) Modeling stakeholder preferences with probabilistic inversion: application to prioritizing marine ecosystem vulnerabilities. In: Linkov I, Ferguson E, Magar V (eds) Real time and deliberative decision making: application to risk assessment for non-chemical stressors. Springer, Amsterdam, pp 265-284

Ott WR (1978) Environmental quality indices: theory and practice. Ann Arbor Science Publishers, Ann Arbor, MI

Pandolfi JM, Jackson JBC, Baron N, Bradbury RH, Guzman HM, Hughes TP, Kappel CV, Micheli F, Ogden JC, Possingham HP, Sala E (2005) Are U.S. coral reefs on the slippery slope to slime? Science 307:1725-1726

Parrish FA, Boland RC (2004) Habitat and reef-fish assemblages of banks in the Northwestern Hawaiian Islands. Mar Biol 144:1065-1073

Riebesell U, Schulz KG, Bellerby RGJ, Botros M, Fritsche P, Meyerhofer M, Neill C, Nondal G, Oschlies A, Wohlers J, Zollner E (2007) Enhanced biological carbon consumption in a high $\mathrm{CO}_{2}$ ocean. Nature 450:545-548

Rivera MAJ, Kelley CD, Roderick GK (2004) Subtle population genetic structure in the Hawaiian grouper, Epinephelus quernus (Serranidae) as revealed by mitochondrial DNA analyses. Biol J Linnean Soc 81:449-468

Sale PF (2008) Management of coral reefs: where we have gone wrong and what we can do about it. Mar Poll Bull 56:805-809

Selkoe KA, Halpern BJ, Toonen RJ (2008) Evaluating anthropogenic threats to the Northwestern Hawaiian Islands. Aquat Conserv 18:1149-1165

Stewart RR, Noyce T, Possingham HP (2003) Opportunity cost of ad hoc marine reserve design decisions: an example from South Australia. Mar Ecol Prog Ser 253:25-38

Vroom PS, Page KN, Peyton KA, Kukea-Shultz JK (2005) Spatial heterogeneity of benthic community assemblages with an emphasis on reef algae at French Frigate Shoals, Northwestern Hawaiian Islands. Coral Reefs 24:574-581 